\title{
In-laws and outlaws: black magic among Pakistani migrants in Denmark
}

\author{
Mik Kel Ryt Te R University of Copenhagen
}

\begin{abstract}
This article explores how suspicions of kala jaddu (black magic) restructure local and transnational family networks among Pakistani immigrants in Denmark. The notions of 'working' and 'stealing' are analysed as two idioms that sum up what it means to 'be' and 'do' family. 'Working' refers to the expectations and moral obligations of the traditional patrilocal household, 'stealing' to the appropriation of emotional and material means through the use of kala jaddu. It is argued that black magic is employed to contest authority and reorganize transnational migrant networks, and that growing anxieties about kala jaddu are due to intergenerational changes within Pakistani families, as well as to the changing political climate towards immigrants in Danish society.
\end{abstract}

Mumtaz leaned forward and looked me straight in the eyes: 'I suspect at least one of my sons to be afflicted by kala jaddu! (black magic)'. Mumtaz, a Pakistani woman in her mid-fifties and the mother of five grown-up children, has been living with her husband in a suburb of Copenhagen since the early 1970s. She agreed to relate her life story to me and thus contribute to my fieldwork on Pakistani migration to Denmark. ${ }^{1}$

Before she revealed her anxieties about whether her son might be a victim of sorcery, we had already met a couple of times and talked about her life and family situation. Now, in order to convince me of her suspicions, she went through the circumstances that she saw as critical evidence for the social diagnosis of black magic: her son Bilal had always been such a good boy, had never smoked, consumed alcohol or done anything wrong, and always respected his parents and seniors in general. But after he married a young woman from Pakistan, he had started behaving in peculiar ways. Several times he had taken sides with his wife when he and his mother had been fighting over everyday incidents in the household, and he accused his mother of lying. However, the most incriminating evidence was that, during a six-month stay in Pakistan - four months longer than originally intended - his wife had persuaded him to buy an apartment of their own without even telling Mumtaz. So when the girl finally returned to Denmark, she went directly to the couple's new apartment without even visiting her mother-in-law. This was not normal. Bilal would never do something like that! 
After this crucial incident, Mumtaz decided to do some research on her own, using her networks in Pakistan, and she discovered that the mother of her daughter-in-law actually had a reputation in the local area in Punjab for knowing and practising kala jaddu. This convinced Mumtaz that her daughter-in-law and the latter's mother had performed sorcery on Bilal while she was in Pakistan.

Recovering from the bewilderment that the sudden turn in our conversation had left me in, I asked what she could do in response. Mumtaz breathed a deep sigh of relief. All she could do now for Bilal in order to deal with the critical situation in her family was to pray and read the Qur'an. Using kala jaddu was not to be seen as a victory for her in-laws, but rather as their defeat. Mumtaz refrained from using illegitimate powers in order to win Bilal back and rhetorically asked: 'As long as I can work, then why would I steal?'

This article explores how and why Pakistani migrant families experience being targeted by kala jaddu, which is most often performed by members of their extended family in Pakistan. The two extended cases of Mumtaz and Nazia, representing the first and second generations of Pakistani women in Denmark, respectively, will be used as prisms for the more general discussion of disruptive family and kinship structures, as well as of changing notions of relatedness within transnational migrant networks.

It is a common experience among the approximately 25,000 Pakistanis who have been living in Denmark since the late 1960s that their cherished institution of the family has been subject to radical changes in recent years, as traditional structures of obligation, loyalty, and responsibility between close relatives disappear or are rapidly reconfigured. The consequent insecurity and uncertainty are associated with the reappearance of kala jaddu in many families and personal narratives being used as a social diagnosis by migrants in vulnerable positions to explain the inexplicable.

A starting-point in this analysis is that the practices and beliefs of kala jaddu should not be dismissed as merely folk religion or superstition, but taken seriously as yet another way to 'do' family. In line with recent kinship studies that urge us to look at local idioms of relatedness and the various practices through which people construct lasting ties of emotion and responsibility (Carsten 2000), kala jaddu will be analysed as a particular way of pursuing family struggles by supernatural means and of relating to each other. The cases of Nazia and Mumtaz deal with in-laws situated in Pakistan who are suspected of using illegitimate means to influence family affairs and to rearrange relationships within the Danish branch of the family. In this way, both cases address the ambivalence within global kinship networks between consanguineous and conjugal families. Suspecting one's in-laws of kala jaddu not only suggests that they are deliberately trying to harm you and thus violating common codes of morality and decency; it also implies that they have definitively parted company with Islam. By reaching a critical social diagnosis of kala jaddu, one's in-laws are therefore reconfigured as outlaws.

\section{A marginalized discourse}

In anthropological terminology, kala jaddu falls under the category of 'sorcery', that is, a deliberate infliction directed at specific victims. ${ }^{2}$ As such, kala jaddu should be confused neither with nazar ('the evil eye'), the innate and often uncontrollable witchcraft of jealous people (Sachs 1983; Spooner 1970), nor with autonomous and sometimes evil-spirited non-human creatures like jinn, bhut, or churail, which have been 
reported once in a while as interfering with the everyday family life of Pakistanis at home and abroad (Ballard 2006: 165; Ewing 1997; Khan 2006; Shaw 2000: 210ff.).

There are only a few empirical studies of how kala jaddu affects family life. Studies of Pakistani migrant communities (Ballard 2006; McLoughlin 1998; Shaw 2000; Werbner 2003), more traditional village studies in South Asia (Marsden 2005; Carstairs 1983; Callan 2007; Varley 2008) and studies of Sufi mysticism (Ewing 1997, 1998; Werbner and Basu 1998) have touched on the theme of kala jaddu, but even here the phenomenon is only briefly mentioned as a curiosity. The marginal position of kala jaddu in the literature reflects the ways in which ethnographers approach issues of family and religion in Pakistan studies. Researchers may have been too willing to accept their interlocutors dismissing suspicions of kala jaddu within family networks as irrelevant, folk religion or merely superstition, ${ }^{3}$ or when representatives of the 'new born religious' second generation explain such practices away as leftovers from the 'cultural' practices and beliefs of their parents (see, e.g., Jacobson 1998; Johansen 2002; Schmidt 2004). This has led many scholars of Islam in the Diaspora to focus on religious leaders and authorities, ignoring the more popular practices as a pale and deviant shadow of what is supposed to be the true Islam (Ballard 2006: 162).

Even though suspicions of kala jaddu tend to be reduced to a marginal discourse of family affairs, they are nevertheless a significant aspect of lived experience. According to Roger Ballard, magic is part of the kismetic dimension of religious life, referring to those ideas and practices - for example, visiting shrines and seeking the assistance of living and dead saints - that South Asians may use to explain the otherwise inexplicable, and, having done so, to stop adversity in its tracks (Ballard 1999: 17). The kismetic dimension constitutes a folk theory of causality that gives reason to misfortune and enables counter-actions within the predetermined cosmic order of Islam.

Despite a growing interest in the kismetic dimension among Pakistanis in Denmark, kala jaddu continues to be a disputed aspect of family life, epitomizing unresolved tensions in the community between notions of culture vs religion and tradition vs modernity. In her psychologically inspired approach to Sufism in Lahore, Katherine Pratt Ewing (1997) argues that her interlocutors encounter and relate to multiple discourses simultaneously. These 'shifting selves' explain how interlocutors from the upper middle class cope with being intellectual, rational, and modern while at the same time being attracted to the emotional, mystical, and traditional universe of Sufism. Ewing's ethnography emphasizes that Islamic mysticism (or the kismetic dimension) is not simply 'traditional', as many religious reformists would have it. Instead the dichotomy of tradition and modernity is mutually constitutive, while the shifting selves are a basic condition of postcolonial subjects, enabling them to navigate within and between supposedly contradictory discourses (Ewing 1997: 26). In this respect, Ewing's argument is in line with newer studies of 'occult economies' (witchcraft, sorcery, magic, etc.) in Africa that transcend the dichotomy of tradition and modernity, arguing that emerging occult economies are highly modern phenomena, not leftovers from a previous 'traditional' lifestyle, but rather constitutive of modernity itself (Comaroff \& Comaroff 1999; Geschiere 1997; Moore \& Sanders 2001: 12).

Following on from these insights, the etic analysis of this article goes beyond the emic descriptions of my Danish-Pakistani interlocutors, which often present kala jaddu as proof of the tough 'village mentality' (landsbymentalitet) presumably found among 'cultural' people and 'traditional' families of rural origin. I argue, on the contrary, that the preoccupation with rumours and suspicions of kala jaddu must be understood as 
a thoroughly modern manifestation of the uncertainty and moral disquiet following from ruptures of the family institution and the dubious status of Muslim immigrants in the Danish welfare state in recent years.

\section{Navigating religious dimensions}

When asked about black magic, many interlocutors reply like Freha, a young DanishPakistani woman: 'Kala jaddu exists. It says so in the Qur'an'. In attempting to convince a non-Muslim like myself of this fact, some recite the sura on how the angels Harut and Marut brought magic into the world in the time of old Babylon as a temptation to test people, saying, 'We are merely a trail and a temptation, so do not disbelieve' (sura al-baqarah 2: 102). Or they explain how later, during the lifetime and reign of the Prophet Salayman (Solomon), disbelieving jinns taught people how to use magic to cause separation between husband and wife (Al-Sha'rawi 1995: 35). Others present evidence from the sunnah relating the hadith of how the Prophet Muhammad himself was targeted by black magic on one occasion. The object that caused the harm was made out of hair taken from a comb the Prophet had used, which had then been hidden in the well of Dharwaan. In a dream, the malicious object and the site where it was hidden were revealed to the Prophet. When the well was filled in, the spell was broken (Ameen 2005: 182). These stories prove the existence of kala jaddu within a Muslim universe; whoever denies this fact is a kaafir, a non-believer (Ameen 2005: 183). Reporting this evidence from the Qur'an and sunnah situates the existence of black magic within some of 'the primal scenes of Islam' (Fischer \& Abedi 1990: 50, in McLoughlin 2009: 244) and orthodox tradition. In this respect, kala jaddu becomes an ontological and cosmological fact that one has to deal with.

Some Pakistani interlocutors argue that the Prophet was only struck by black magic because he was an extraordinary example in every way. Black magic exists, but not among the common people. Others have a more 'rational' approach, stating that probably only a few of the cases diagnosed as kala jaddu are actually so. From this perspective, suspicions of kala jaddu are primarily a means for people to avoid taking personal responsibility for unfortunate events in their lives and family. Arguments in this sense could be that it is people's own fault if they get divorced, or that it is understandable that newly wed sons and daughters-in-law wish to leave the patrilocal household to obtain some privacy. Diseases are a natural and inevitable part of life, and childlessness can have many other causes than sorcery committed by envy and jealous members of the extended family. This kind of 'rational' argumentation is common among well-educated second-generation Pakistanis, who think their parents and representatives of the first-generation cohort exaggerate the threat of sorcery and are often far too quick to conclude that misfortunes are caused by kala jaddu.

Still, many Pakistanis will seriously consider whether or not they might be victims of sorcery if they are struck by inexplicable misfortunes and their lives are suddenly turned upside down. This was the case with Mariam, a young university student, who was engaged to Hassan. Their match was the result of a crush leading to numerous telephone calls, Internet correspondence, and secret meetings. Despite the reluctance of the families, the young couple were determined to get married and planned a controversial love marriage. ${ }^{4}$ Everything seemed fine, but just a few weeks before the wedding, Hassan broke off the engagement without any further explanation. Mariam was devastated. What had happened? What had changed between them? She went through all the disagreements they might have had, but without reaching a logical explanation for 
Hassan's rejection of her. Finally she consulted a gifted friend, who provides spiritual investigation, to find out whether Hassan had been struck by kala jaddu, perhaps by his mother, who did not approve of the rishta (marriage connection), or by a jealous aunt in Pakistan, who had her own daughter lined up for a marriage on the rebound if her nephew's engagement was broken off. The friend concluded, however, that this was not a case of kala jaddu. Apparently, Hassan had simply changed his mind. Still, the case shows how Mariam, who normally would never have suspected, nor believed in, kala jaddu, treated it as a reasonable explanation for the inexplicable change in her life trajectory and future horizons.

Anyone can end up in a situation like Mariam, where one has to consider seriously the possibility of kala jaddu. Even though ideas and beliefs in kala jaddu are said to be stronger in the first-generation cohort than in the second, and presumably more salient among women than men, owing to the gendered organization of public and private spaces (see Rasanayagam 2006), the kismetic dimension of religious life continues to be present as a reservoir that migrants can mobilize or risk being exposed to. As Rizwan, an unmarried man in his early thirties, explained: 'Many young people say they do not believe in kala jaddu, but that does not mean that they cannot be struck by it!'

\section{Pakistanis in Denmark}

Pakistanis started coming to Denmark as 'guest workers' in the late 1960s. In 1973 the Danish government banned further labour-related immigration, but Pakistanis kept coming to Denmark through the policy of family reunification. Today approximately 25,000 people residing in Denmark have a family history related to Pakistan, and it is estimated that approximately 75 per cent originate from the villages in Gujrat district in rural Punjab (Quraishy 1999). As most Pakistanis in Norway originate from the same area, it is often referred to as 'Little Scandinavia'.

With economic recession and increasing unemployment in the late 1970s and 1980s, many semi-skilled Pakistanis lost their jobs and became self-employed in running restaurants, travel agencies, small groceries (kiosks), or taxis (Hjarnø 2000). These businesses were run and financed with the help of local networks of trusted friends, fellow villagers, and members of the extended family. These prosperous occupational niches, along with investments in real estate, have made many families well-off economically.

Over the years, Pakistani families have become closely interrelated through overlapping networks of family, friends, political activity, education, business, or religious activity. The criss-crossing life trajectories and family stories have resulted in a villagelike community, spread out over the geographical area of Copenhagen and its suburbs, where it is generally believed that 'everyone knows everyone else'. An important aspect of community life is the ongoing circulation of gossip and strong mutual social control.

The relative economic success of the Pakistanis has generated an environment of fierce competition in which families strive to accumulate economic, cultural, and symbolic capital in order to gain honour and respect (Rytter 2009, in press). When the second generation entered the free Danish educational system, school performances and educational achievements became yet another competitive arena. As a result, young Danish-Pakistanis today distinguish themselves from other immigrant groups by having an educational level that is almost equivalent to their average Danish peer group (Moldenhawer 2005). 
As Pakistani migrants settled in Denmark, they began reconstructing the social, cultural, and religious universe they knew from back home. An unexpected consequence of the settlement process has been that other aspects of local Punjabi life have followed as well. Pnina Werbner explains: 'As migrants have travelled to the west so too have their afflictions and the harmful spirits associated with them. The global reach of Sufism is, it seems, also the global reach of jinns, jaddu and other malevolent influences' (2003: 223). Living in European urban settings for decades has not made occult forces disappear. On the contrary, there seems to be a renewed interest in spiritual matters and a growing market for Copenhagen-based 'helpers' whom migrants can consult in order to find out if they themselves or someone in their close family has been struck by kala jaddu. ${ }^{5}$

\section{Studying kala jaddu}

Within a village-like migrant community, where everyone protects their family's reputation, people are often reluctant to give an outsider access to the family sphere. The general precaution is intensified in the case of Pakistanis as they have been rather negatively represented in the Danish media. ${ }^{6}$ It can therefore be difficult to study a sensitive topic such as kala jaddu.

First of all, kala jaddu is not something people talk about openly. Suggesting it as an explanation for misfortune is only done in the company of family or close friends - and definitely not to a non-Pakistani like myself, who is not expected to understand. One reason for this precaution is that no one will risk being ridiculed for being 'superstitious' or 'backward'. Another reason is that you can never really trust anyone. Because this kind of illicit magic is most often performed by family members, business partners, or friends who envy your life, material belongings, or success, you can never be sure that those with whom you share urgent anxieties of kala jaddu are not those responsible for it in the first place.

Secondly, kala jaddu is a sensitive topic because it deals with problematic family relations and domestic power struggles, used under different circumstances and with varying purposes such as:

\footnotetext{
to harm an enemy or rival, such as a senior sister-in-law, to make someone agree with you, to make someone fall in love with you, to hide love affairs from parents, to control errant teenagers, to make a son accept a marriage he does not want, or to draw a husband's attentions, affections and duties towards yourself and your parents and away from your in-laws (Shaw 2000: 209).
}

Rumours and suspicions of kala jaddu are potentially disruptive, and should be treated with discretion. Finally it is important to stress that anyone who performs kala jaddu, or makes others do so, will automatically exclude themselves from Islam (Ameen 2005: 202). Those who none the less do so are considered to be outlaws, living outside the moral order of decent people. In this way, knowledge of or even the slightest interest in kala jaddu is highly suspicious. This is a topic one is not supposed to know anything about. $^{7}$

It is generally believed that kala jaddu is carried out in Pakistan by sorcerers who will charge you money for their evil deed. Interlocutors explain that it is always possible for migrants in Denmark to call someone in Pakistan, who can go to a local sorcerer and have him or her perform the magic for you. Apparently this kind of black magic is not affected by the distance between Pakistan and Denmark. I have only a little anecdotal 
information on how kala jaddu is done in practice. Most often it is explained as the effect of a ta'wiz, an amulet that will affect you when, for instance, it is hidden in your house or garden. To be powerful, such a magical device should be made out of the hair, nails, or personal belongings of the victim, just as happened to the Prophet Muhammad himself. The ta'wiz can also be dissolved in water or hidden in food and afterward consumed by the victim. If the evil ta'wiz enters the body, the effect is supposedly much more devastating. Finally, some claim that kala jaddu is achieved by reorganizing the words and sayings of the holy Qur'an. Just as the word of God is believed to have healing powers, so too it can have severely negative effects if it is mixed up in the right (or one might say wrong) way.

Despite these methodological obstacles, I have been collecting stories and experiences of kala jaddu for a great part of my fieldwork among Pakistanis in Denmark. Some have been related by those who have experienced them, others are stories that interlocutors have related about their friends or family members. In this way, I have tried to tune into discourse and follow the ongoing gossip. As part of my fieldwork in Pakistan, I have also visited shrines and some of the living pirs (saints) whom migrants themselves consult in Pakistan if they suspect that they are the victims of kala jaddu.

Having clarified how kala jaddu relates to both Islam and family life, I now move on to discuss the cases of Mumtaz and Nazia in greater detail.

\section{Mumtaz's story}

Mumtaz, who was introduced at the beginning of this article, lives with her husband Salman in a villa south of Copenhagen. The couple have been blessed with five children - three sons and two daughters - and five grandchildren. For many years they were self-employed, but today Salman is retired and has handed over the business to his sons, and all the children have left the house. Mumtaz regrets that none of her sons lives with her, as the tradition of the patrilocal household prescribes. She feels very lonely.

After arriving in Denmark in the early 1970s, Salman worked in a factory, and as money was scarce, they had to rent a room in the flat of another Pakistani couple. After an accident in which Salman suffered a complicated fracture, he lost his job, and they had to live on sickness benefits for almost a year. Therefore Mumtaz and the two children were sent back to Pakistan, where for more than three years she lived with her mother-in-law and her husband's unmarried sisters. In 1976 she had to return to Denmark because the family wanted her to have more children.

Once again Mumtaz had to suffer the embarrassment of living in a rented room in the apartment of another Pakistani couple, but after a while they succeeded in finding a little apartment they could afford. Meanwhile the extended family's wishes were fulfilled when Mumtaz gave birth to more children. In order to have a second income in the household, she later started working at different unskilled jobs.

Like many other Pakistani families, in the early 1980 os Salman and Mumtaz opened a kiosk, but they quickly sold it again after being harassed and racially abused by a gang of grønjakker (a local version of skinheads). Instead they started an import company. The business soon became a financial success, so in 1990 they left their crowded apartment and moved into a big house with their grown-up sons and, later on, the latters' newly arrived wives from Pakistan. This was when the problems began.

According to Mumtaz, there are two types of daughter-in-law: those from Pakistani families in Denmark, and those found in Pakistan. The first is brought up in day-care institutions and schools, has Danish friends, and has learned the 'Danish way' of not 
showing respect towards teachers, parents, and authorities in general. Like many other migrant parents, Mumtaz has tried to overcome these problems by selecting rishta (marriage connections) for her children in Pakistan, but today she has learned otherwise:

Pakistani spouses are lazy and spoiled. They are brought up like hens in a cage in (often high-class) protective families, but when they arrive in Denmark, they suddenly become free birds. They do not know hard work or the value of money, and will not even take advice from their mothers-in-law. This is a real headache.

However, Mumtaz does see differences between her daughters-in-law. Whereas Saima, the wife of her oldest son, is Mumtaz's sister's daughter and came to Denmark when she was just 17, the wives of Bilal and his brother were in their mid-twenties when they arrived. They had been selected from the wider biraderi (classificatory brotherhood) and came from influential families in Gujrat city. These girls quickly learned Western manners. While Mumtaz herself was a pioneer in Denmark and had to work her way up, her daughters-in-law arrived in established and well-off families:

They come here with their Bollywood fantasies of what married life should be about, and suddenly they can become queens in their own little kingdoms. They have an urge to leave the house of their mother-in-law and get their own place to rule over.

After arriving in Denmark, the two daughters-in-law not only changed mentally, they also started dyeing their hair and wearing contact lenses. One of the girls even replaced her traditional dresses with jeans and revealing blouses. Mumtaz asked her either to change her clothes or to leave the house. She felt that her 'daughters' should not dress like that in her home.

The conflicts went on until all three sons left the house. Two of them still have contact with Mumtaz, but the connection with Bilal has effectively been cut off. By using kala jaddu, Mumtaz's in-laws have taken Bilal away from her.

\section{Nazia's story}

Nazia is a Danish-Pakistani woman in her early thirties. Together with her husband and their three children, she lives in a suburb of Copenhagen. She is just about to finish her education as a nursery teacher.

When Nazia was a child, her father and mother had a very bad marriage, and they 'were never nice to each other'. Back then, her mother always told Nazia and her siblings that the marriage problems were the result of kala jaddu performed by her mother-inlaw and sister-in-law, Nazia's grandmother and aunt in Pakistan. Their motives for trying to ruin the marriage were apparently envy of her mother's life and many opportunities in Denmark.

Today Nazia's siblings are married in Pakistan, but she herself is married to Jens, a Danish non-Muslim. Once, Nazia refused a suitor while she was on holiday in Pakistan. Her mother called from Denmark and asked Nazia's uncle to take a tuft of her hair and bring it to 'the right people', in order to change her mind by using kala jaddu. Her uncle refused to do so, but the confrontation left Nazia with the disturbing knowledge that her mother would not refrain from using illicit powers in order to make her behave properly and obey her. 
Years later Nazia fell in love with her current husband, Jens, and they got married without the agreement of Nazia's parents. This controversial move made the young couple the centre of inquisitive gazes and ongoing gossip in the local Pakistani neighbourhood, so Nazia and Jens decided to move to another part of Denmark. For years Nazia had no contact with her family, except with one of her sisters. But then they decided to return to the city.

While living apart from her parents, Nazia had at one time found what looked like flecks of blood on her wallpaper. A Pakistani friend had confirmed the findings to her as kala jaddu material. This made her worry that her mother might be using magic to get her back. The suspicion grew stronger after they returned to Copenhagen, and Nazia started visiting her parents again in order for her children to meet and become acquainted with their grandparents. After a while, Nazia and Jens went through a big marital crisis. Again she had to consider seriously whether this was the result of her mother's sorcery.

According to Nazia, her mother had from the very beginning interpreted Nazia's falling in love and marrying Jens as itself a case of kala jaddu, though not by Jens or his family, who as Danes and non-Muslims presumably had no knowledge of it. Instead she suspected that the love match and eventual marriage were the result of kala jaddu performed by her enemies in the extended family network in Pakistan. They obviously wanted to harm her, and did so by taking Nazia away from her.

Later Nazia learned from her sister that, at the time when she was not living in Copenhagen, the family found a bundle of bones buried in the back yard of the house. Each bone had one of the children's names inscribed on it. Immediately her mother concluded that family members in Pakistan had been trying to split up her family and take her children away from her. However, Nazia and her sister also discussed the possibility that it could be their mother herself who had performed kala jaddu on the children in order to keep them nearby as an intimate part of her life. Even though Nazia tried to distance herself from her mother, she still played a crucial part in her life. This might indicate that magic was involved.

\section{Working and stealing}

Nazia and Mumtaz dread the notion that kala jaddu has shaped their life trajectories. Both cases concern struggles for power and authority in the context of intimate relations between husband and wife, parent and child or in-laws. Furthermore, both reveal the tensions and ambivalence that migrants may feel towards members of the extended family, especially in-laws in Pakistan. In this respect, the cases highlight important ideas of what it means to be and do family in local and transnational migrant families.

Janet Carsten (2000: 3) suggests that we take indigenous idioms of relatedness seriously in order to explore how family and kinship are produced and reproduced locally. Recent studies have shown great variety and inventiveness in the means, ideas, and practices that people utilize in order to relate to one another and create lasting bonds of emotion and obligation. In migration studies, this perspective has been used to explore how transnational family networks are maintained or restructured over time (Bryceson \& Vuorela 2002; Eastmond \& Åkesson 2007; Olwig 2007). Mumtaz gives an important clue through which we may comprehend her current situation and anxiety about kala jaddu when she rhetorically asks: 'As long as I can work, then why would I steal?' Her question highlights a basic understanding where being and doing family are equated with a continued effort, while arrogating resources through kala jaddu is 
represented as an act of stealing. Basically 'working' means doing and being family in traditional ways, whereas 'stealing' becomes an act of reorganizing relations, love, and loyalty.

\section{The idiom of work}

In her study of the Pakistani community in Oxford, Alison Shaw (2000) discusses a number of different social and ritual practices in which families participate to stress the principle of fraternal solidarity. Most important is lena-dena (taking-giving), in which migrants exchange gifts at life-cycle events. On these occasions, the amount of money that has been given is recorded so that a gift can be returned on a later occasion (Shaw 2000: 227ff.). Moral expectations surrounding gift exchange are also an omnipresent principle in the social organization of Pakistani families in Denmark. However, the patterns of exchange have different temporalities. Whereas some gifts (in the broadest analytical sense) are reciprocated within a short time, in other instances people spend years making financial and emotional sacrifices in order to receive a similar gift in the future.

One example is the 'intergenerational contract' between parents and children in the patrilocal family system. In the Islamic religious tradition, and as a widespread practice in many Pakistani migrant families, it is the duty of parents to raise and nurture children in the best way possible, and then to give them away in marriage. In return sons are obliged to take care of their parents in their old age. Another, similarly significant example is the expectation and moral obligation that in-married girls should show respect for the elders of the new family in the patrilocal household. Ideally the mother-in-law has the final say in domestic matters as a result of the position she has achieved in the family hierarchy. A daughter-in-law should comply with the desires and wishes of her mother-in-law, knowing that her time will come to occupy the same position.

In both scenarios, 'working' means subordinating oneself to the structures and hierarchies of the patrilocal household. The personal sacrifice this may cost one is widely accepted, as everyone knows that in time they will receive similar treatment.

Nazia related how, years ago, her older brother wanted to marry a wife from Denmark, but his mother pressured him to change his mind. Instead he ended up marrying the young Pakistani woman his mother had already chosen for him. Accordingly, Nazia's decision to marry without the consent of her parents was a clear violation of the expectations and asymmetrical power of the parent-child relationship. Her deed was condemned not only by the family, but also in the wider Pakistani community.

Similarly, Mumtaz regretted the fact that her daughters-in-law violated the basic moral principles of what it means to do and be family: 'They show too little respect when they desist from living together, eating together, sitting, talking or praying together'. In contrast to many Pakistani migrant women in Denmark, Mumtaz had actually experienced being a daughter-in-law in the patrilocal household while living in Salman's mother's house in Pakistan during the 1970s. After Mumtaz was sent back to Denmark, she and Salman were blessed with two boys. When Salman's mother called from Pakistan, she greeted them first, then asked for one of the boys: 'You have two sons, and I have none. Let me have one of them'. So Mumtaz had to send one of her babies to Pakistan to be brought up in the house of her mother-in-law. Crying, she explained that accepting the wishes of Salman's family was a sign of respect. 
Mumtaz's current frustration with her daughters-in-law stems from the fact that she has always subordinated herself to the demands of the patrilocal family, and worked hard in order to provide the financial and emotional means they required. She has done her duty and is now supposed to be enjoying the fruits of her efforts, but this is where black magic is interfering with her future prospects.

\section{The idiom of stealing}

When Mumtaz's daughters-in-law first arrived in Denmark, they all lived together in the villa as an extended family, but their everyday life was full of conflicts. According to Mumtaz, the girls spent too much money and in 'wasting time on make-up, ending up looking like dolls'. She had even seen them take money from the petty cash of the family company in order to go shopping, leading her to jump on her sons who had just taken over Salman's business, calling them irresponsible and incompetent. But worst of all, Bilal's wife had taken boxes containing different articles from the company's stock and brought them to Pakistan as gifts for her own family. The conflict reached its climax when Bilal bought a new apartment and left the parental household with his wife and daughter. Mumtaz regrets that, in the current situation, Bilal is giving all his love, time, and affection to his young and beautiful wife. In other words, she is receiving the treatment to which Mumtaz feels entitled. This is the real theft, the loss that has led Mumtaz to decide upon a social diagnosis of kala jaddu.

Similarly, Nazia's story illustrates how different members of the extended family continuously try to manipulate or control each other by using kala jaddu. According to Nazia, the main motivation for her mother's suspect actions and ongoing anxieties is a deep-seated fear that someone will take her children from her, just as she experienced when Nazia married Jens and later left the family and moved to another part of the country.

The extended cases of Mumtaz and Nazia deal not only with domestic struggles over power and resources, but also with ambivalences towards members of the transnational family in Pakistan. Both cases are in line with recent studies of family and kinship. From an analytical perspective, kala jaddu is a way of relating to others, not in a 'constructive' way, in which partners exchange symbolic and material objects in order to bring family members together and strengthen the moral connections and obligations between them, but as an abrupt way of reorganizing families. In this respect, kala jaddu, both as mere suspicion (with actual implications) and as a concrete malicious practice, can be interpreted as a way to 'cut the network' (Strathern 1996). In line with this, Bruce Kapferer explains:

\footnotetext{
Magical practice and sorcery are major sites of innovation, and their method of invention (a cosmology of invention) is to attack the very ways in which human beings routinely are seen or conceived to construct their realities ... they also do so by extending and adapting already available cosmologies, modes of constructing and patterning, to the pragmatics at issue, to the particularities of the case (2003: 21).
}

Black magic is like a parasite that feeds off the conventional ways of being and doing family, but simultaneously the suspicions and concrete practices of kala jaddu are also methods of invention that reorganize emotion and loyalty within the family, and thus the very morphology of the transnational migrant networks. In particular, the boundary between the consanguineous family and the conjugal family seems to be at issue. In 
Pakistan and among Pakistani migrants, there is a widespread preference for endogamous, arranged marriages (Charsley \& Shaw 2006; Shaw 2001), as a result of which many transnational family networks have been woven together for generations. This preference, however, does not change the ambivalent status of conjugal families, highlighted when Mumtaz explains the differences between daughters-in-law recruited respectively from inside or outside the family, or when Nazia's mother insists that her daughter's life trajectory and their mutual relationship are governed by her in-laws in Pakistan. When it comes to kala jaddu, one's in-laws are the usual suspects.

\section{Institutional breakdown}

The family institution among Pakistani migrants in Denmark is undergoing radical changes owing to demographic shifts combined with economic and social mobility. What used to be the firm foundation of one's life and existence is now crumbling away. Whereas everyone used to 'work' together, now they have begun to 'steal' from each other. Some see this reconfiguration of tradition as an opportunity enabling them to re-create their lives and future prospects, but for others it is a disturbing development that results in broken illusions, despair, and solitude. In this specific context, kala jaddu has regained its importance.

In this last section, I situate the anxieties of Nazia and Mumtaz regarding kala jaddu within the wider social and political context of the Danish welfare state and discuss the institutional breakdown of the family on the local, national and transnational levels.

\section{The local level}

Like many older Pakistanis, Mumtaz suffers from arthritis and diabetes, and she dreads what will become of her and Salman, now that her sons have left the household. She represents a general concern among the older generation over what will happen to them later in life, now that their grown-up children no longer agree on what it means to be and do family in 'proper' ways. Many feel deserted by their children and fear ending up in residential homes, as is common for elderly people in the Danish welfare system.

The insecurity of the first generation is closely connected to the aspirations and social mobility of their well-educated offspring and the latter's spouses. Daughters-inlaw are less likely to accept the same treatment as women of the previous generation did, but often wish to establish their own households. Danish-Pakistani women in particular place a priority on obtaining an education and maybe even having a career - just like their husbands.

In recent years, the tradition of arranged marriages within the biraderi (classificatory brotherhood) in Pakistan has been challenged by the independent second generation, who generally want to choose their spouses themselves. Furthermore, the transnational marriage pattern is hampered by the strict immigration regime introduced in 2002, which makes it virtually impossible for young Danish-Pakistanis to obtain family reunification in Denmark if they marry a spouse from their parents' original homeland. Whereas more than 80 per cent of Danish-Pakistanis formerly married in Pakistan, the most recent survey published in 2004 shows that more than 40 per cent now find their spouses in Denmark (Schmidt \& Jakobsen 2004: 111). Today the figures are probably still higher in favour of marriages within Denmark.

Many Danish-Pakistanis who are denied family reunification move to the Scania region in Sweden, just thirty minutes from Copenhagen, where they are entitled to 
family reunification as citizens of the European Union. Hundreds have used this option since 2002, commuting between work, friends, and family in Denmark, and their accommodation and legal residence in Sweden (Rytter 2007). In this way, legal measures break up families.

The combination of an independent second generation and strict national legislation has resulted in a boom in love marriages. Young people meet, fall in love, and decide to get married before the two families are allowed to take over and arrange the marriage in the traditional way (Rytter 2003; 2005a; 2006; 2009). As the case of Nazia shows, this trend poses a serious challenge not only to the institution of arranged marriages, but also to norms of parental authority, chastity, and honour.

Furthermore, in recent years there has been a rise in divorce cases within the migrant community. Old as well as young interpreted this as a disturbing pattern and as final proof that Pakistanis are becoming 'Danish'. These changing structures of authority and intimacy leave parents of the first generation with less or no control over the life trajectories and future prospects of their children.

\section{The national level}

The legal measures that hamper the practice of transnational, arranged marriages are just one of numerous external policies that have been amended in recent years with the explicit purpose of integrating immigrants into Danish society. This trend started in the 1990s with a growing interest among politicians, the media, and the public in the everyday lives and impact of 'the Muslim family'. Since then Islam and Muslims as such have often been ridiculed in the national media, as during 'the cartoon crisis' (Hedetoft 2006), or else are represented as a serious challenge to the Danish welfare system (Hervik 2002). The Danish public has had debates similar to those found in other European countries concerning Muslim religious practices and family life: for example, the ongoing discussion of whether or not headscarves are a symbol of oppression (Schmidt 2007), whether Muslim children should be allowed special privileges, such as halal food in school, private showers after gym classes, and holidays at Eid, whether workplaces should allow Muslim employees time and space to pray at work, and so on. The urgency of this kind of public discussion and strengthening of political action seems to have intensified since the terror attacks in New York in 2001 and later in London and Madrid. Since then policies and campaigns have been introduced in order to change customs, ideas, and practices that are seen as problematic within the immigrant family. In all aspects of their family lives, Muslim immigrants are subjected to ongoing public interest, scientific investigation, political discussions, and legal measures. The Muslim family is an institution under siege, a factor that increases feelings of insecurity, uncertainty, and a lack of self-determination.

\section{The transnational level}

Pakistanis in Denmark have, over the years, tried to maintain intimate relations with people and places in Pakistan through various transnational practices, such as communication, regular visits, remittances, and by erecting houses on the family property. Lately there has also been a significant traffic in dead bodies being flown to Pakistan to be buried (Rytter 2005b). But, as mentioned above, the most important means of maintaining intimate relations with extended family networks is transnational, arranged marriages. 
Today the meaning and content of these transnational relations are changing. Whereas migrants might try to cut down on remittances or the frequency of journeys to Pakistan, the family 'back home' often treats the migrants solely as a means of access to the wealth of the West. Being situated in Denmark, migrants must accept being cheated of their property and heritage in Pakistan, and they may find that their house has been occupied by tenants who refuse to move - sometimes even family members. The family in Pakistan sometimes sees the migrants as a means of obtaining financial resources or as a way of getting their own sons or daughters into Denmark. Studies report that unmarried girls living in Europe are simply referred to as 'visas' in local Pakistani discourses (Wikan 2002: 262) or tell of 'bogus' marriages when South Asian men trick families into allowing them to marry their daughters, only to divorce them as soon as they acquire citizenship (Charsley 2006: 1170). In this way, cherished family relations have in many respects become purely instrumental.

How the institutional breakdown of the traditional extended family is related to changes on the local, national, and transnational levels, respectively, deserves to be analysed further. In this article, the three levels merely serve to frame the stories of Mumtaz and Nazia, and to suggest that the domestic struggles and tensions they experience within these transnational networks are by no means unique. On the contrary, they represent the more general concerns experienced by Pakistani migrants in Denmark.

\section{Conclusion}

This article has argued that suspicions of kala jaddu have become salient among Pakistani migrants in Denmark as a way of reorganizing family relations within local and transnational networks. The current preoccupation with kala jaddu should not be interpreted as a return to, or a reinvention of, tradition. Rather, it should be viewed as a thoroughly modern response to the growing uncertainties and insecurities that Pakistani migrants face as a result of changing ideas of what it means to be and do family, as well as the eroding legitimacy of Muslim immigrants in Denmark.

An important argument regarding the reappearance of modern magical practices concerns their disjunction from the past and the radical reconfiguration of the ideas and practices of the past in terms of the circumstances of the present (Kapferer 2003: 19). Owing to the limited literature on kala jaddu, it is not possible to follow the trajectory of the phenomenon in time and space, but as it belongs to the kismetic dimension of religious life, as part of the historically constituted repertoire of postcolonial migrants, it has most likely been there all along (see Ballard 1999; Ewing 1997). In his historical study of the Bakweri in Cameroon, Edwin Ardener (1970: 141) suggests that witchcraft may be subject to fashions, as beliefs are readjusted over time in response to the changing social and economic conditions of the local society. His conclusion supports contemporary assertions that occult economies are forever changing, alive to the basic rhythms of our world over the longue durée (Moore \& Sanders 2001: 11). Likewise kala jaddu has for long been a marginal discourse of family affairs, but the emerging crisis has made suspicions of sorcery return with a vengeance within the migrant community. One feature of kala jaddu that is definitely new in the migratory context is the scope of the destructive-productive forces operating within the transnational social field stretched out between Pakistan and Denmark.

A challenge for future research will be to explore the connections between transnational migration, disruptive family and kinship structures, and cultural production in 
relation to emerging occult economies. For the time being we can only wonder whether or not circulating suspicions of witchcraft, sorcery, or the like, might be a more general condition influencing the everyday life of transmigrants worldwide.

I end by returning to Mumtaz. Whereas Evans-Pritchard's classic study of the Azande (1976 [1937]) dealt with the 'how' and the 'why' of witchcraft beliefs, recent studies suggest that witchcraft can be equated with a social diagnosis that not only allows people to explain how and why they are struck by misfortune, but also to act on their situation and move on (Whyte 1997). Reaching the social diagnosis of kala jaddu not only explains to Mumtaz and those around her why her family is falling apart, it also makes it possible for her to take action against this. She might not get Bilal back in the near future, but she can work in an attempt to change her situation, for example by saying $d u$ 'a (prayer) for him. Paradoxically, her current unfortunate situation has strengthened her position within the neighbourhood network of Pakistani mothers, where she has gained the reputation of someone who is familiar with the experience of troublesome sons and daughters-in-laws and of being the victim of kala jaddu. The social diagnosis of kala jaddu not only makes sense of her loss, but also allows her to regain control over a world that is changing rapidly around her. She can start working in order to get her life back on track and re-establish a meaningful future horizon, despite the current critical situation.

\section{NOTES}

A first draft of this article was presented at the 'Mega-seminar' hosted by the Danish Research School of Anthropology at Sandbjerg, 14-16 January 2008. I am grateful to my colleagues Bjarke Oxlund, Ann Benwell, Morten Nielsen, Roger Ballard, Nils Bubandt, Susan Reynolds Whyte, Robert Parkin, Karen Fog Olwig, and the two anonymous JRAI reviewers for many valuable comments and relevant suggestions on how to improve the argument. Finally I thank the Christian og Ottilias rejselegat for yngre videnskabsmænd og kvinder and the Danish Institute in Damascus for funding my fieldwork in Pakistan.

${ }^{1}$ The material presented in this article was collected in 2006 and 2007 as part of the ethnographic fieldwork for my Ph.D. thesis entitled 'Family upheaval: generation, mobility and relatedness among Pakistani migrants in Denmark' (2009). All names of informants in the article are pseudonyms. The study is part of a larger research programme on 'The family as an institution of integration among refugees and immigrants in Denmark' headed by Professor Karen Fog Olwig and located at the Department of Anthropology, University of Copenhagen. The research programme has been funded by the Danish Council for Independent Research/ Humanities (see http://fiid.ku.dk/).

${ }^{2}$ I prefer the term kala jaddu (occasionally translated into English as 'black magic' or 'sorcery') because it was the most common expression used by my interlocutors.

${ }^{3}$ This critique is not directed at the studies mentioned, but rather at the many studies of Pakistani family life that neglect the topic of kala jaddu as a significant realm of domestic struggles and family life.

${ }^{4}$ Love marriage is put in italics because it is an emic expression connoting a modern practice of individual choice. Compared to the standards of the average Danish teenager, these love relations leading to marriages are often very innocent. Being in love or having a romantic relationship does not necessarily imply that one has physical intimacy before the actual wedding (see Rytter 2003).

5 'I do not know what is going on. Suddenly there seem to be holy men (hellige mand) all over the place', a Danish-Pakistani friend of mine burst out during a conversation we had over the telephone. This was his immediate reaction to the fact that not only one of his 'uncles', the father of the family living next door, but also one of his old friends from the neighbourhood had started receiving worried visitors, investigating whether they were the victims of kala jaddu, blowing dam (a ritual cleansing technique), or offering vasifa (specific prayers).

${ }^{6}$ In 1996, a Danish newspaper ran a series of articles on how families from the village of Mandeer lived on more or less illegal activities and sent the money to Pakistan. In the summer of 2001, young members of the transnational organization Idara Minhaj-ul Quran were exposed in the media, suspected of attempting to infiltrate the Danish Folketing (parliament) in order to overthrow democracy. And in 2005 the brutal 'honour' 
killing of Ghazala Khan, a young Pakistani woman, was in the headlines. Episodes like these have not only given Pakistanis a bad reputation with the Danish public, they have also confirmed that conveying private information might place you in the headlines.

${ }^{7}$ Travelling in rural Punjab with a Danish-Pakistani friend in the autumn of 2007, visiting shrines and living pirs (saints) and conducting interviews in the local area about kala jaddu, we joked about how him helping me collect data would affect his ability to find a wife in the area later on. The fact that a gora (a white man) and an unmarried man related to one of the influential families of the village were making this kind of investigation raised suspicions. Why this interest, and what were we up to?

\section{REFERENCES}

AL-ShA'RAwi, S.M.M. 1995. Magic and envy - in the light of Qur'an and Sunna. London: Dar Al Taqwa.

AMEen, A.K.I. 2005. The jinn and human sickness: remedies in the light of the Quran and Sunnah. Riyadh: Darussalam.

Ardener, E. 1970. Witchcraft, economics and the continuity of belief. In Witchcraft confessions and accusations (ed.) M. Douglas, 141-60. London: Tavistock.

Ballard, R. 1999. Panth, kismet, Dharm te Qaum: continuity and change in four dimensions of Punjabi religion. In Punjabi identity in a global context (eds) P. Singh \& S.S. Thandi, 7-37. Oxford: University Press.

2006. Popular Islam in northern Pakistan and its reconstruction in urban Britain. In Sufism in the West (eds) J. Malik \& J. Hinnels, 160-86. London: Routledge.

Bryceson, D. \& U. Vuorela (eds) 2002. The transnational family: new European frontiers and global networks. Oxford: Berg.

Callan, A. 2007. 'What else do we Bengalis do?': Sorcery, overseas migration, and the new inequalities in Sylhet, Bangladesh. Journal of the Royal Anthropological Institute (N.S.) 13, 331-43.

Carstairs, G.M. 1983. Death of a witch: a village in North India 1950-1981. London: Hutchinson.

Carsten, J. (ed.) 200o. Cultures of relatedness: new approaches to the study of kinship. Cambridge: University Press.

Charsley, K. 2006. Risk and ritual: the protection of British Pakistani women in transnational marriage. Journal of Ethnic and Migration Studies 32, 1169-87.

— A. SHAw 2006. South Asian transnational marriages in comparative perspective. Global Networks 6, 331-44

Comaroff, J. \& J. Comaroff 1999. Occult economies and the violence of abstraction: notes from the South African postcolony. American Ethnologist 26, 297-303.

EAstmond, M. \& L. Åkesson (eds) 2007. Globala familjer: transnationell migration och släktskap. Göteborg: Gidlunds.

Evans-Pritchard, E.E. 1976 [1937]. Witchcraft, oracles and magic among the Azande. Oxford: Clarendon Press.

EwING, K.P. 1997. Arguing sainthood: modernity, psychoanalysis, and Islam. Durham, N.C.: Duke University Press.

1998. A majzub and his mother: the place of sainthood in a family's emotional memory. In Embodying charisma: modernity, locality and the performance of emotion in a Sufi cult (eds) P. Werbner \& H. Basu, 160-86. London: Routledge.

Fischer, M.J. \& M. Abedi 1990. Debating Muslims: cultural dialogues in postmodernity and tradition. Madison: University of Wisconsin Press.

Geschiere, P. 1997. The modernity of witchcraft: politics and the occult in postcolonial Africa. Charlottesville: University of Virginia Press.

Hedetoft, U. 2006. Denmark's cartoon blowback: on OpenDemocracy (available on-line: http:// www.opendemocracy.net/faith-europe_islam/blowback_3315.jsp, accessed 16 November 2009).

Hervik, P. 2002. Mediernes Muslimer: en antropologisk undersøgelse af mediernes doekning af religioner Danmark. Copenhagen: Schultz Forlag for Nævnet for Etnisk Ligestilling.

HJARNø, J. 200o. Indvandrere som selverhvervende - en sammenlignende analyse af udbredelsen af selverhverv hos danske pakistanere, tyrkere og eksjugoslavere. Dansk Sociologi 11: 3, 95-112.

JACOBSON, J. 1998. Islam in transition: religion and identity among British Pakistani youth. London: Routledge. Johansen, K. 2002. Muslimske stemmer: religiøs forandring blandt unge muslimer i Danmark. Viborg: Akademisk Forlag.

KAPFERER, B. 2003. Beyond rationalism: sorcery, magic and ritual in contemporary realities. New York: Berghahn. 


\section{MIKKEL RYTTER}

Khan, N. 2006. Of children and jinn: an inquiry into an unexpected friendship during uncertain times. Cultural Anthropology 21, 234-64.

McLoughlin, S. 1998. 'An underclass in purdah'? Discrepant representations of identity and experiences of Young-British-Asian-Muslim-Women. Bulletin of the John Rylands University Library of Manchester 80: 3 , 89-106.

2009. Contesting Muslim pilgrimage: British-Pakistani Identities, sacred journeys to Makkah and Madinah, and the global postmodern. In Pakistani diasporas, culture, conflict and change (ed.) V. Kalra, 233-66. Oxford: University Press.

Marsden, M. 2005. Living Islam: Muslim religious experience in Pakistan's North-West Frontier. Cambridge: University Press.

Moldenhawer, B. 2005. Transnational migrant communities and education strategies among Pakistani youngsters in Denmark. Journal of Ethnic and Migration Studies 31, 51-78.

Moore, H.L. \& T. SANDERS 2001. Magical interpretations and material realities: an introduction. In Magical interpretations, material realitites: modernity, witchcraft and the occult in postcolonial Africa (eds) H.L. Moore \& T. Sanders, 1-26. London: Routledge.

Olwig, K.F. 2007. Caribbean journeys: an ethnography of migration and home in three family networks. Durham, N.C.: Duke University Press.

Quraishy, B. 1999. Fra Punjab til Vesterbro: det pakistanske samfund i Danmark. Copenhagen: Forlaget Etnisk Debatforum.

Rasanayagam, J. 2006. Healing with spirits and the formation of Muslim selfhood in post-Soviet Uzbekistan. Journal of the Royal Anthropological Institute (N.S.) 12, 377-93.

Rytter, M. 2003. Lige gift: en antropologisk undersøgelse af arrangerede agteskaber blandt pakistanere $i$ Danmark (Specialerækken 261). Department of Anthropology, University of Copenhagen.

2005a. Ægteskab som bevægelse: positioner og interesser i et arrangeret ægteskab. In Lokale liv, fjerne forbindelser: studier af børn, unge og migrationsprocesser (eds) L. Gilliam, K.F. Olwig \& K. Valentin, 265-82. Copenhagen: Hans Reitzels Forlag.

2005b. Til døden os skiller ... eller forener: oplevelser af hjem og tilhørsforhold blandt pakistanere i Danmark. Social Kritik 99, 42-9.

2006. Ægteskabelig integration: pakistanske og danske arrangerede ægteskaber. In Den stille integration: nye fortollinger om at høre til i Danmark (eds) M.H. Pedersen \& M. Rytter, 18-43. Copenhagen: C.A. Reitzels Forlag.

2007. Giftermål över gränserna: arrangerade äktenskap bland dansk-pakistanier i Malmö. In Globala familjer: transnationell migration och släktskap (eds) M. Eastmond \& L. Åkesson, 175-204. Göteborg: Gidlunds.

2009. Family upheaval: generation, mobility and relatedness among Pakistani migrants in Denmark. Ph.D. thesis, Department of Anthropology, University of Copenhagen.

- in press. Money or education? Strategies of improvement among Pakistani families in Denmark. Journal of Ethnic and Migration Studies, special issue on 'Scandinavia'.

SACHS, L. 1983. Evil eye or bacteria: Turkish migrant women and Swedish health care (Stockholm Studies in Social Anthropology 12). University of Stockholm.

Sснміdт, G. 2004. Islamic identity formation among young Muslims: the case of Denmark, Sweden and the United States. Journal of Muslim Minority Affairs 24: 1, 31-45.

2007. Muslim i Danmark-Muslim i Verden: en analyse af muslimske ungdomsforeninger og muslimsk identitet $i$ årene op til Muhammad-krisen. Uppsala: Universitetstryckeriet.

— \& V. JаKовSEN 2004. Pardannelse blandt etniske minoriteter i Danmark. Copenhagen: Socialforsknings Instituttet.

Shaw, A. 2000. Kinship and continuity: Pakistani families in Britain. Amsterdam: Harwood Academic.

2001. Kinship, cultural preference and immigration: consanguineous marriage among British Pakistanis. Journal of the Royal Anthropological Institute (N.S.) 7, 315-34.

Spooner, B. 1970. The evil eye in the Middle East. In Witchcraft confessions and accusations (ed.) M. Douglas, 311-19. London: Tavistock

Strathern, M. 1996. Cutting the network. Journal of the Royal Anthropological Institute (N.S.) 2, 517-35.

VARLEY, E. 2008. Belaboured lives: an ethnography of Muslim women's pregnancy and childbirth practices in Pakistan's embattled, multi-sectarian northern areas. Doctoral thesis, Department of Anthropology, University of Toronto.

Werbner, P. 2003. Pilgrims of love: the anthropology of a global Sufi cult. London: Hurst. 
\& H. BASU (eds) 1998. Embodying charisma: modernity, locality and the performance of emotion in Sufi cults. London: Routledge.

Whyte, S.R. 1997. Questioning misfortune: the pragmatics of uncertainty in eastern Uganda. Cambridge: University Press.

WiKan, U. 2002. Generous betrayal: politics of culture in the new Europe. Chicago: University Press.

\section{Mariage et errements : la magie noire parmi les migrants pakistanais au Danemark}

\section{Résumé}

L'auteur explore la manière dont les soupçons de magie noire (kala jaddu) restructurent les réseaux familiaux locaux et transnationaux des immigrés pakistanais au Danemark. Les notions de « travail » et de " vol » sont analysées comme deux idiomes qui résument ce que signifie " être » et " faire » une famille.

"Travail » renvoie aux attentes et aux obligations morales de la maisonnée patrilocale traditionnelle, « vol » à l'appropriation de moyens émotionnels et matériels par le recours à la kala jaddu. L'auteur avance que la magie noire est employée pour contester l'autorité et réorganiser les réseaux de migrants transnationaux et que l'inquiétude grandissante à son sujet résulte des changements intergénérationnels dans les familles pakistanaises autant que du changement de climat politique vis-à-vis des immigrés dans la société danoise.

Mikkel Rytter is a Ph.D. fellow at the Department of Anthropology, University of Copenhagen.

Department of Anthropology, University of Copenhagen, Øster Farimagsgade 5, 1353 Copenhagen K., Denmark. mikkel.rytter@anthro.ku.dk 